\title{
Özlem Aytekin
}

İstanbul Ayvansaray University, ozlemaaytekin@gmail.com, İstanbul-Turkey

\begin{tabular}{l|l|l}
\hline \hline DOI & http://dx.doi.org/10.12739/NWSA.2021.16.2.D0273 \\
\hline ORCID ID & $0000-0002-4794-8910$ \\
\hline Corresponding Author & Özlem Aytekin \\
\hline
\end{tabular}

\section{GEÇMİŞTEN GÜNÜMÜZE KAĞIT KESME (CUT OUT) TEKNİ̆̆̇ VE YAPILAN DENEYSEL ÇALIŞMALAR}

\section{Öz}

Mısırlıların papirüs, Çinlilerin kâğıt alanında sağladıkıarı gelişmelerle birlikte kâğıt, yazı yazma dışında kulıanılarak, kâğıt kesme (cut out) tekniğiyle çeşitli çalışmalar ortaya koyulmuştur. Çinlilerin kâğıtla yaptıkları çalışmalar neredeyse tüm ülkeleri etkileyerek farklı isimler verildiği görülmektedir. Deneysel resimleme tekniklerinden kâğıt kesme tekniği, ilk zamanlar geleneksel yöntemlerle yapılırken teknolojik gelişmelerle farklı bir boyut kazanarak dijital ortamda da üretilebilir ve sunulabilir hale gelmiştir. Bu araştırma ile kâğıt kesme tekniğinin tarihsel gelişimi, kağıt kesme tekniği ve günümüzde kâğıt kesme tekniğiyle ortaya koyulan çalışmalar anlatılarak Türkçe litaretüre katkı sağlamak istenmiştir. $\mathrm{Bu}$ alanda yapılan sanat, tasarım ve illüstrasyon çalışmaları irdelenerek bu teknik kullanımı ile nitelikli daha fazla yaratıcı çalışmaların ortaya koyulabilmesi için teşvik edici olması amaçlanmaktadır.

Anahtar Kelimeler: Kâğıt Kesme Tekniği, Kâğıt Kesme Sanatı, Deneysel Resimleme Tekniği, İllüstrasyon, Kağıt

\section{PAPER CUT OUT TECHNIQUE AND EXPERIMENTAL STUDIES FROM PAST TO PRESENT}

\section{ABSTRACT}

It was seen that paper was used beyond writing with the improvements made by the Egyptians in the field of papyrus and the Chinese in the field of paper, and various works were carried out with the paper cut out technique, one of them. The works made by the Chinese with paper affected almost all countries and gave different names. While the paper cutting (cut out) technique, one of the experimental techniques, was initially performed with traditional methods, it gained a different dimension with technological developments and became available in digital environment. In this article, it is aimed to reveal more creative works with the use of this technique by giving information about the historical development of the paper cutting technique, the cut out technique and the current studies with the paper cutting technique.

Keywords: Cut Out Technique, Paper Cutting Art, Experimental Illustration Technique, Experimental Illustration, Paper 


\section{GİRIŞ (INTRODUCTION)}

Kâğıt kesme tekniği çeşitıi yaratıcı çalışmalara olanak tanıyan, uzun bir geçmişe dayanan, Çinliler tarafından geliştirilen bir halk sanatıdır. Çalışmalar incelendiğinde kağıdın bilgiyi kaydetme dışında çeşitli amaçlarla kullanıldığı görülmektedir [3]. İlk ortaya çıktığı zamanlarda Kuzey Çin'deki kasvetli olan evlere hafif renk ve lşık vermesi için kırmızı renkte çalışmalar yapıldığı görülmektedir. Bu çalışmaları Çinliler 'pencere çiçekleri' olarak adlandırmışlardır. Aynı zamanda bu süslemeler noel havası da vermiştir. Bunun dışında evlerde kullandıkları bazı eşyalarda çeşitli süsleyici özelliklere sahip bu tür çalışmalar olduğu söylenebilir. Süsleyicilik dışında bolluk, bereket, uzun ömür gibi sembolik anlamlar, dini amaçlar ve kültürel adetler gibi birçok amaç için de yapılmıştır [9]. Çiçek, hayvan gibi formları oluşturmak çok zor değildir ancak bu kesme tekniğine uygun kesici aletlerle yaratıcı çalışmalara dönüştürmek bilgi, tecrübe, yetenek, deneyimleme ve hayal gücü gerektirmektedir. Maket bıçağı, makas ve kretuar gibi araçlarla katlama yapılarak kesilebileceği gibi katlama olmadan da oyularak ya da parça parça kesilip birbiriyle ilişkilendirilerek bir araya getirilebilir. İlüustratörün/resimleyenin bilgisiyle, tecrübesiyle ve isteği doğrultusunda kâğıt kesme tekniğinde kullanılan yöntem ve ortaya çıkan çalışmalar da çeşitlenebilir.

\section{2. ÇALIŞMANIN ÖNEMI (RESEARCH SIGNIFICANCE)}

Kâğıt kesme tekniğiyle ilgili Türkçe literatür eksikliği bulunmakta ve uluslararası yapılan çalışmalarla kıyaslandığında yetersiz kaldığı sonucuna varılarak araştırma konusu olarak ele alınmıştır. Kâğıt kesme tekniğinin tarihsel gelişiminden kısaca bahsedilerek, günümüzde her sanatçının kendine özgü üslup ve yöntemle ortaya koyduğu çalışmalar örneklerle anlatılmıştır.

\section{ARAŞTIRMA YÖNTEMI (RESEARCH METOD)}

Kâğıt kesme tekniği kapsamında önemli bilgilere yerli yabancı literatür taraması yapılarak ulaşılmış ve bu araştırma betimsel analiz yöntemiyle gerçekleştirilmiştir. Sanatçıların kâğıt kesme tekniğini kullanarak illüstrasyon, grafik tasarım ve sanat alanında özgün, deneysel, yaratıcı çalışmalar ortaya koyabileceği örneklerle gösterilmiştir.

\section{KÂĞIT KESME TEKNIĞİNIN TARİHSEL GELIŞฺ̇MI (HISTORICAL DEVELOPMENT OF PAPER CUTTING TECHNIQUE}

İnsanoğlu var olduğu günden beri kendini ifade etmenin çeşitli yollarını aramıştır. Bunlar ilk zamanlar mağara duvarlarına çizilen resimler olurken, yazının bulunmasıyla uygarlıklar kitaplarını kil, fildişi, yaprak gibi malzemelere yazmışlardır. Daha sonraları M.Ö.2. yüzyılda ilk kâğıt üretimi yapılmıştır. İık örneklere bakıldığında artık olan paçavra, dokuma gibi malzemelerin bir araya getirilerek hamura dönüştürüldüğü ve kalıplarla şekillendirmeler yapıldığı görülmektedir. Zamanla bu artık malzemeleri terk ederek kenevir, bambu kâğıt dutu, dut ağacının iç kabuğu ve jüt hint kamışı gibi yaşadıkları yerlerde çokça bulunan malzemelerle kâğıt üretmeye başlamışlardır. Çinliler kâğıt yapımını bir sır gibi sakladıkları için Kore, Japonya ve Türkistan M.S.7. yüzyılda öğrenebilmiştir. Milattan sonra ilk bin yılda, kâğıdın yayılmasında Budist çalışmaların önemli etkisi olmuştur [5].

Kâğıt yapmayı öğrenen Bağdat, M.S.794 yıllarında seri üretim amacıyla fabrikalar inşa ederek dünyada kâğıt üretim merkezi haline gelmiştir. Kâğıt üretiminin keşfiyle birlikte modern bir sanat etkinliği olarak kâğıt kesme tekniği ortaya çıkmıştır. Bu teknik 
kullanımıyla süsleme amacıyla yapılan çalışmaların yanı sıra sembolik anlamlar içeren ve dini amaçlarla yapılan çalışmalar olduğu da görülmektedir. Papirüsün ortaya çıktığı Mısır'da ise kâğıt kesmeye dair herhangi bir şeye rastlanmamıştır [10]. Mao, cenaze törenlerinde ölüleri kâğıt kesme çalışmalarıyla yaktıklarını ya da gömdüklerini söylemektedir [7].

Tang hanedanı döneminde yaşanan hanedanlık savaşları ve değişim sebebiyle kâğıt kesme tekniği güneye doğru kaymış, cesur renk kullanımları ile birlikte işlenen konulara yenileri eklenmiştir [9]. Çinliler bu tekniğe Jian Zhi adını vermişlerdir. Zamanla yayılan bu teknik diğer ülkeler tarafından da uygulanmış ve Almanya'da 'Scherenschnitte', Ukrayna ve Polonya gibi ülkelerde 'Wycinanki' (veechin-non-key), Japonya'nın Edo Döneminde 'monkiri' Osmanlı döneminde 'Katı' adını almıştır. Hristiyan kilisesinin yüzyıllar boyunca kullanımını yasaklamaya çalıştığı güçlü bir unsur olsa da Yahudilerle ticaret yapan Müslümanların bu yolla kâğıda erişebilmesi ile çok erken bir endüstri olarak ortaya çıkmış ve Türkler bir şekilde ticaretini gerçekleştirmişlerdir.

Katı sanatı olarak da bilinen bu çalışmaların ilk örneklerine 15. yüzyılda rastlandığı görülmektedir. Kat veya katı 'kesmek' anlamındadır. Materyal kullanımında farklılık olsa da bir yazıyı, motifi, şekli oyup çıkararak, bir başka kâğıt ya da deriye yapıştırarak oluşturulan bir süsleme sanatı olarak açıklanabilir. 16. yüzyılda kâğıt oymacıları birliği kurularak ve 1582'de bahçeler kaleler, minyatürler bu çalışmalarla süslenmiştir. Gölge oyununda kullanılan kesme tekniğiyle yapılan kuklaların tasarımına da ilham olmuştur [4, 10 ve 11].

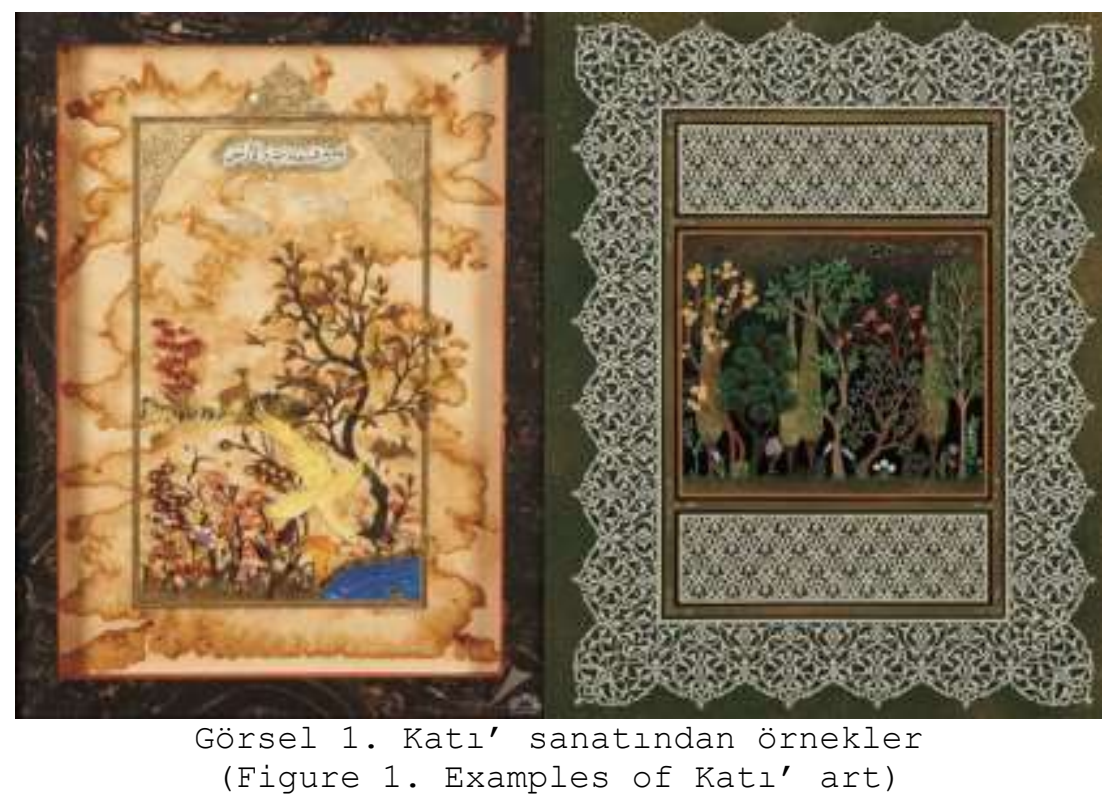

Çin'de işçilerin ve kadınların kâğıt kesmek için kullandıkları makas, maket bıçağı gibi araçlarda daha becerikli olduklarından bir köylü ve kadın sanatı olarak kabul görmüştür. O dönemlerde, yemek pişirme gibi her kadından beklenilen bir uğraş olmuştur. Büyükten küçüğe kâğıt kesme öğretilerek sonrasında gençler doğaçlama olarak kendi formlarını, çalışmalarını oluşturmuşlardır [1]. Çin'in hemen hemen her yerinde uygulanır hale gelmiş ve en çok çalışılan formlar ise hayvanlar, karanfiller, şakayıklar, bambuların yanı sıra lahana ve pancar gibi tarımsal ürünler olmuştur. Bunların dışında çocuklar için nar, şeftali, çam uzun yaşamın sembolü olmuş ve limon, bereketli bir 
hasatı simgelemiştir. Şehirlerdeki popüler olan kesimler ise tarihi şahsiyetler ve halk hikâyeleri olduğu söylenebilir. Çocukların oyun oynaması, dans etmesi gibi kâğıt kesme tekniği insanlar tarafından eğlenceli bir alan olarak da görülmüştür [10].

Polonya kesme tekniğinde yapılan çalışmalar çoğunlukla ladin ağacı ve horoz gibi Paskalya geleneğinin sembolleri ve simetrik kesimler olmuştur. Çalışmalar daha çok tek renkliyken zengin olan bölgelerde farklı renkler de kullanılmıştır. Kâğıt daha sonraları erişilebilir hale geldikçe kâğıt kesme tekniği kırsal alanlara yayılmış ve stilize edilmiş sıradan tarım işçileri, hayvanlar ve bitkiler çalışma konularını oluşturmuştur. Almanya'da ve İsviçre'de siyah-beyaz kâğıt ile oluşturulan kontrast formların daha çok yapıldığı söylenebilir. Almanya'da kâğıt kesme "Scherenschnitte" olarak adlandırılmış ve daha çok aşk mektupları yazmak için kullanılmıştır. Bu teknikle genç erkekler sevgilerini ifade etmek amacıyla mektuplar yapmışlardır. Mektuplarda narin, dantel gibi harfler keskin bıçaklarla kesilmiş ve bazen de sulu boya ile boyanarak süslenmiştir. Önemli yazar Hans Christians Andersen, kâğıt kesme tekniği ile bazı çalışmalar yapmış ve sanatçılara ilham olmuştur. Makas kullanarak oluşturduğu basit kesimlerin dışında sanatçının simetrik ve ayrıntılı kompozisyonları da bulunmaktadır. Çalışmalarını siyah fon üzerine, kestiği beyaz kâğıdı yapıştırarak uygulamıştır. Hollandalılar da kağıt kesme tekniği ile resmi ve dini belgeleri süslemişlerdir. Avrupalılar kâğıt üretiminde kendi kendine yetene kadar Osmanlı Türkleri ve Mısırlılardan kâğıt almaya devam etmiştir. Japonya'nın Edo Dönemi'nde ise katlayarak kestikleri 'Monkiri' olarak adlandırdıkları bu çalışmalardan keyif aldıkları anlaşılmaktadır [2 ve 10]. Kâğıdın ulaşılabilir hale gelmesiyle ve profesyonel olarak bu işi yapmaya başlayanlarla birlikte bu teknik kullanımı yaygınlaşmaya başlamıştır [10]. 17. ve 18. yüzyıllarda kâğıt kesme tekniğiyle yapılan illüstrasyonların popüler hale gelmesiyle bu teknik kullanımının farklı disiplinlerle birleştirildiği görülmektedir. Kâğıt kesme tekniğiyle yapılan illüstrasyonun animasyonla birlikte kullanımı Alman sanatçı Lotte Reinenger'in filmlerinde görülmektedir [11]. Bu teknikle ortaya koyulan çalışmalar değerlendirildiğinde hem yaratıcı, sıra dışı eserlere olanak tanıdığı hem de izleyen kişinin yaratıcı kişilik gelişimine katkıda bulunduğu söylenebilir.

\section{GÜNÜMÜZDE KÂĞIT KESME (PAPER CUTTING TODAY)}

Kâğıt kesme tekniği sanatsal alanlarda bilgili ve ilgili kişilerce genellikle keşfedilmektedir. Bu teknik illüstratörlere ve sanatçılara daha yaratıcı çalışmalar ortaya koyabilme imkanı sağlamaktadır. Günümüz tasarımında ve sanat anlayışında yeni anlamlar, kavramlar, stillerle kendine yer edinmiştir. Buna örnek olarak küçüklüğünden beri kâğıt kesme çalışmalarıyla iç içe büyüyen Lu Shengzhong'un çalışmalarında da bu yeni stiller, anlamlar ve kavramlar görülmektedir. Sanatçı için her kâğıt parçası önemlidir ve pozitif kâğıt parçasıyla negatif olan kâğıt parçası bir araya getirildiğinde var olabileceğini söylemektedir [7]. 


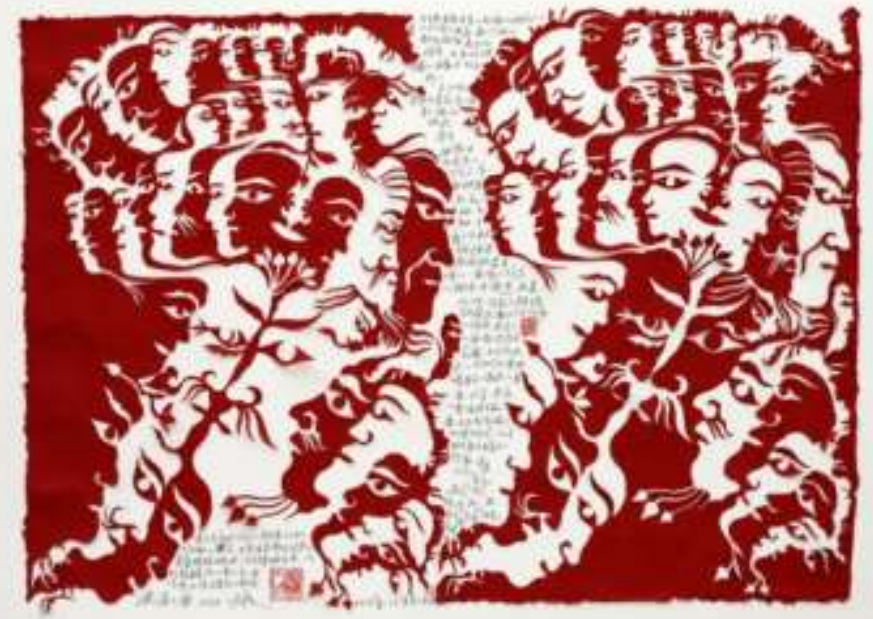

Görsel 1. Lu Shengzhong'un kâğıt kesme çalışmaları

(Figure 2. Lu Shengzhong's paper cutting Works)

\begin{abstract}
Gelişen teknolojiyle birlikte geleneksel yöntemle yapılan kâğıt kesme tekniği sanatçılar tarafından artık dijital ortamda da uygulanabilir hale gelmiştir. Hatta dijital ortam geleneksel yöntemlerle edinilen materyallerden daha fazlasını da sunabilmektedir. Fey de kâğıt kesme tekniğinin geleneksel yöntemle sınırlandırılmadan teknoloji ile birlikte kullanılmasını önermektedir [1]. Birçok yazılım ve donanım aracılığıyla çeşitıi dokular ve renkli kâğıtlar kullanılabilir ve istenildiği gibi kesim uygulanarak farklı tekniklerle boyanabilir. Bir zamanlar kâğıt kesme tekniğiyle yapılan çalışmalar sadece evlerinin yakınında olan kişiler tarafından görülebilirken günümüzde dünya çapında sergileme imkânına sahip olan illüstratörler tarafından dijital platformlar aracılığıyla farklı kültürlere ve büyük topluluklara sunulabilir hale gelmiştir. Özel Sağlamtimur'un da ifade ettiği gibi; illüstratörler, tasarımcılar internet ve dijital mecralar aracılığıyla hemen hemen tüm insanlara çalışmalarını ulaştırabilme imkanına sahip olmuştur [8]. Bu bağlamda değerlendirildiğinde geleneksel yöntemlerle yapılan çalışmaların hangi kültüre ait olduğu tahmin edilebiliyorken günümüzde iletişim olanaklarının ve ülkeler arası etkileşimin artması ile bunun zorlaştığı söylenebilir [10]. Son zamanlarda kâğıt kesmeye dayalı çalışmalar illüstratör ve grafik tasarımcılar tarafından ele alınarak kitap tasarımlarında, kitap resimlemelerinde, web sitesi ve bloglarda kullanıldığı görülmektedir [2]. Bunların dışında Songürdağ'ın da belirttiği gibi sanat nesnesi haline getirilerek kâğıt kesme ile çok büyük enstalasyonlar yapanlar da bulunmaktadır [11]. Bu teknikle oluşturulan çalışmalarla ifade zenginleştirilerek içerik, biçim, form açısından farklı bir anlatımla izleyicinin dikkatini üzerine
\end{abstract} kolaylıkla çekebilmektedir.

\title{
5. KÂĞIT KESME TEKNİĞİYLE YAPILMIŞ ÖRNEKLER (EXAMPLES MADE WITH THE CUT OUT TECHNIQUE)
}

Kâğıt çoğu yaratıcı uygulamalarla birleştirilerek kesildiğinde nasıl etkileyici bir unsura dönüştürülebileceğini son zamanlarda sanatçılar ortaya koydukları çalışmalarla göstermektedir. Beyaz kâğıt üzerinde negatif boşluklar kesilerek oluşturulduğu gibi renkli kâğıtlarla da bu işlem yapılabilmektedir. Eskiden geleneksel tekniklerle ortaya koyulan çalışmalar, teknolojinin gelişmesiyle birlikte tamamen dijital ortamda çeşitli yazılımlar kullanılarak da çalışılabilir hale gelmiştir. Tasarımcılar ve sanatçılar kâğıt kesme 
tekniğini ele alışlarındaki farklılıklarla daha da zengileştirebilir ve yaratıcılıklarını konuşturabilir [3]. Wang Xiaying, kâğıt kesme tekniğine yeni bir stil katan, devam etmesinde önemli katkılar sağlayan öncü isimlerdendir. Kâğıt kesme çalışmalarını daha canlı ve anlamlı hale getiren ve zenginleştiren geleneksel olan tek renkli kağıt kulıanımına, çok renkli kâğıtları da katan bir sanatçıdır. Nokta, çizgi, ritim, renk gibi tasarım elemanlarını kompozisyona dahil etmektedir [6]. Bağımsız bir illüstratör olan Kyle Bean, kavramsal çalışmalarıyla tanınmakta ve selfridges, BBC ve Louis Vuitton için yaratıcı çalışmalar ortaya koymaktadır. Birçok malzeme ile çalışmasına rağmen daha çok kâğıtla çalışmayı tercih ettiği bilinmektedir [2]. Mia Pearlman, bir çizime bağlı çalışmayı sevmediği için daha çok taslak biçiminde çizerek çalışmasına başlamaktadır. Birçok renk içeren Helen Musselwhite ise parçaları birbiriyle ilişkilendirerek katmanlandırmaktadır. Ardından bir kutu içerisinde görüntülenecek şekilde çerçevelemektedir [10]. Eiko Ojala dijital ortamda kâğıt kesme çalışmaları yapmaktadır. 3D yazılım kullanmadan üç boyut etkisi vermekte, elde kâğıt keserek oluşturmuş gibi görünmektedir. Dijital ortamın sunduğu olanaklarla da kâğıt kesme çalışmalarının yapılabileceğini göstermektedir [21].
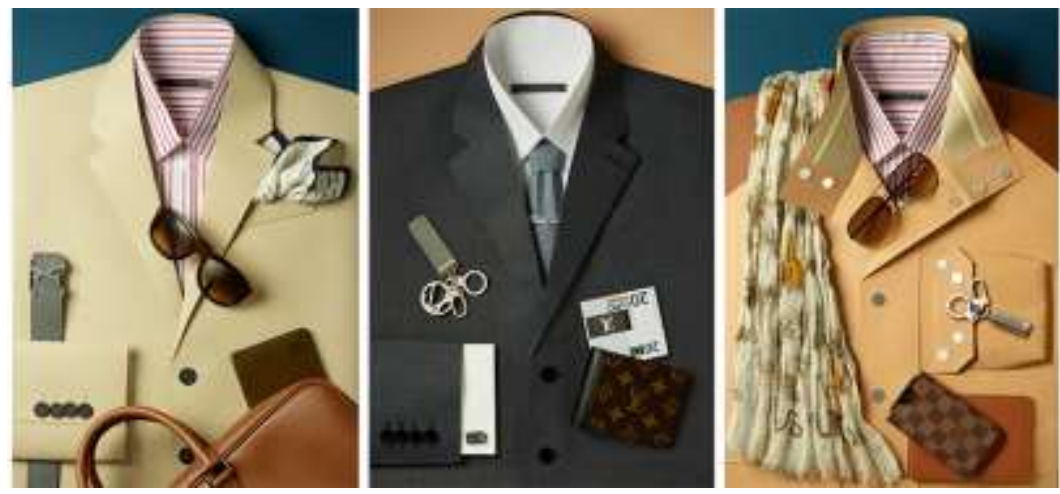

Görsel 3. Kyle Bean'in kâğıt kesme tekniği ile Louis Vuitton için yaptığı çalışmalarından örnekler

(Figure 3. Kyle Bean's Works created for Louis Vuitton with paper cutting tecnique)

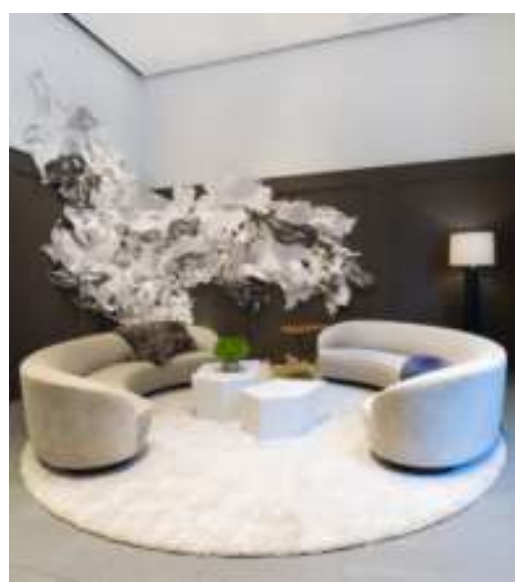

Görsel 4. Mia Pearlman'ın kâğıt kesme çalışması

(Figure 4. Mia Pearlman's paper cutting work)

Elsa Mora'ya göre kâğıt kesme tekniği ile çalışmalar yapmak bir tür meditasyon biçimi ve kendini ifade etme yoludur. Sanatçı kesmeye başlamadan önce çalışmasının neye dönüşeceğini bilmemekte ve bu süreci 
bir tür merak ve keşif süreci olarak tanımlamaktadır. Sanatçı çalışmasına başlamadan önce malzemeyle derin his yaşadığını ve kendisini heyecanlandırdığını söylemektedir [10].
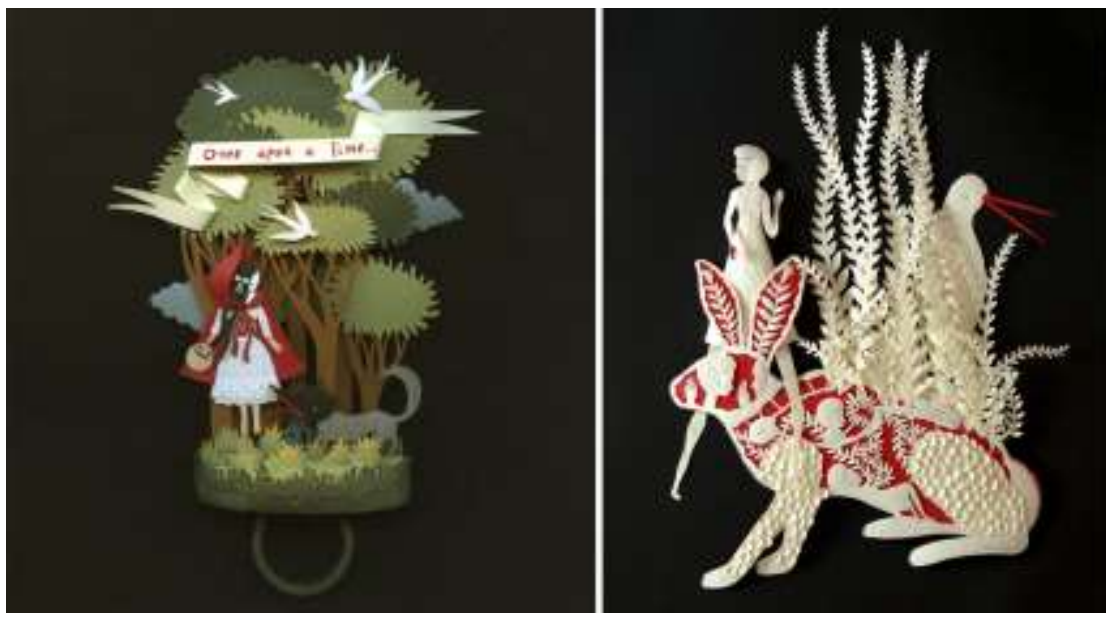

Görsel 5. Elsa Mora'nın kâğıt kesme çalışmaları

(Figure 5. Elsa Mora's paper cutting Works)

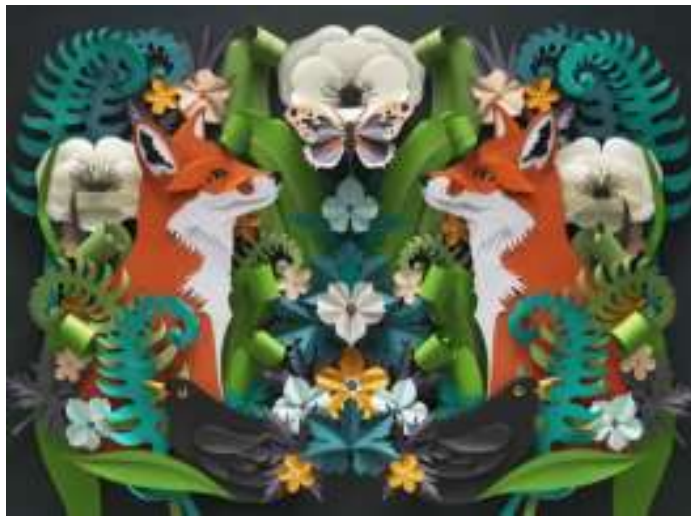

Görsel 6. Helen Musselwhite'ın renkli kâğıt kesme çalışmasından bir örnek

(Figure 6. An example from Helen Musselwhite's study of colored paper cutting)

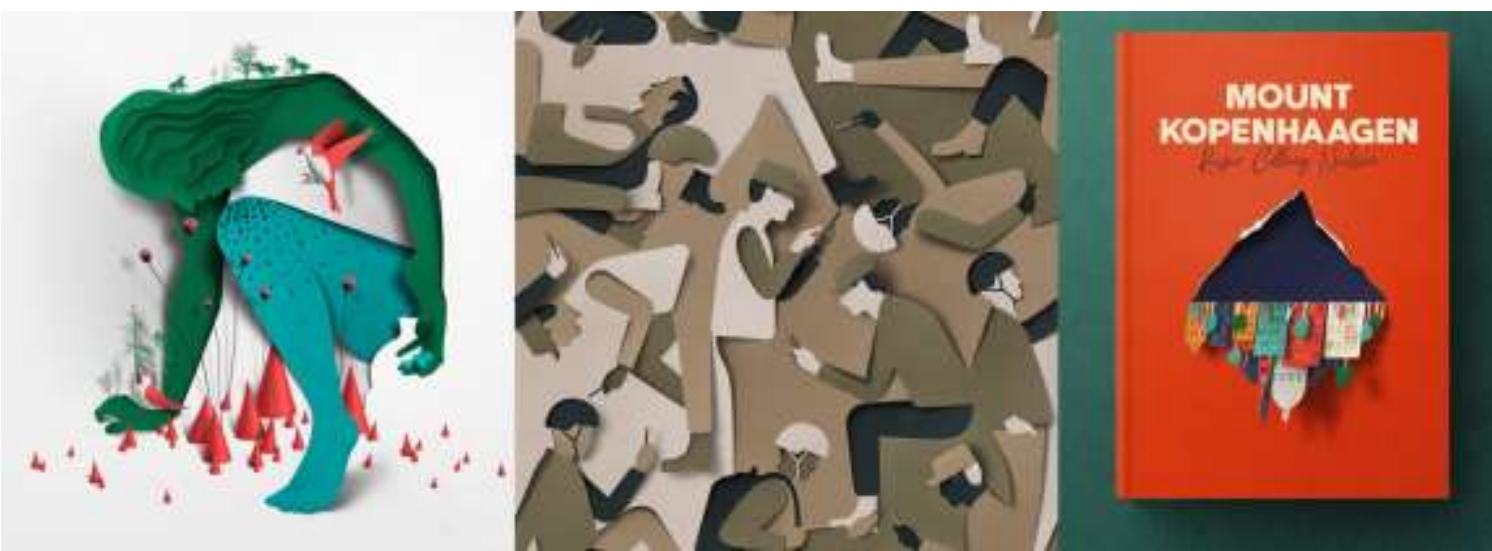

Görsel 7. Eiko Ojala'nın kâğıt kesme tekniğiyle yaptığı çalışmalardan örnekler

(Figure 7. Examples of Eiko Ojala's work with the paper cutting technique) 


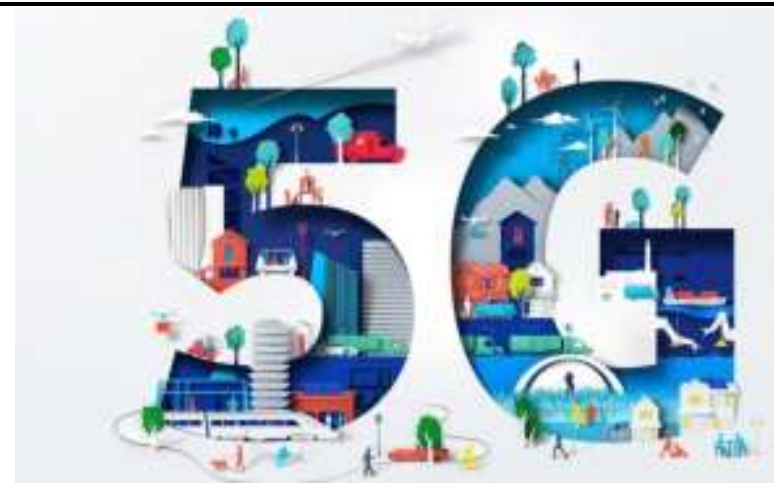

Görsel 8. Eiko Ojala'nın kâğıt kesme tekniğiyle yaptığı çalışmalardan örnekler

(Figure 8. Examples of Eiko Ojala's work with the paper cutting technique)

Çok küçük boyutlarda, kâğıt kesme tekniğiyle oluşturduğu Cindy Fergusan'ın çalışmaları incelendiğinde dinozora binen bir çocuk olabileceği gibi kaplanla yürüyen genç bir kız da olabilmektedir [10]. Maurizio Santucci ve Elisa Cerri tarafından kurulan Bombaland ise İtalya'da bulunan bir illüstrasyon stüdyosudur ve birçok ünlü markayla çalışarak kâğıt kesme tekniğiyle çalışmalar ortaya koymuştur. Bombaland dünyası renkli, zengin muhteşem yaratıklarla doludur ve tamamen kâğıtttan yapılmıştır [19]. Bu bağlamda değerlendirildiğinde illüstratörlerin çıkış noktaları geleneksel kâğıt kesme olsa da her birinin bu teknik kullanımına yeni yöntem ve yaklaşım getirdiği anlatımı zenginleştirdiği söylenebilir.

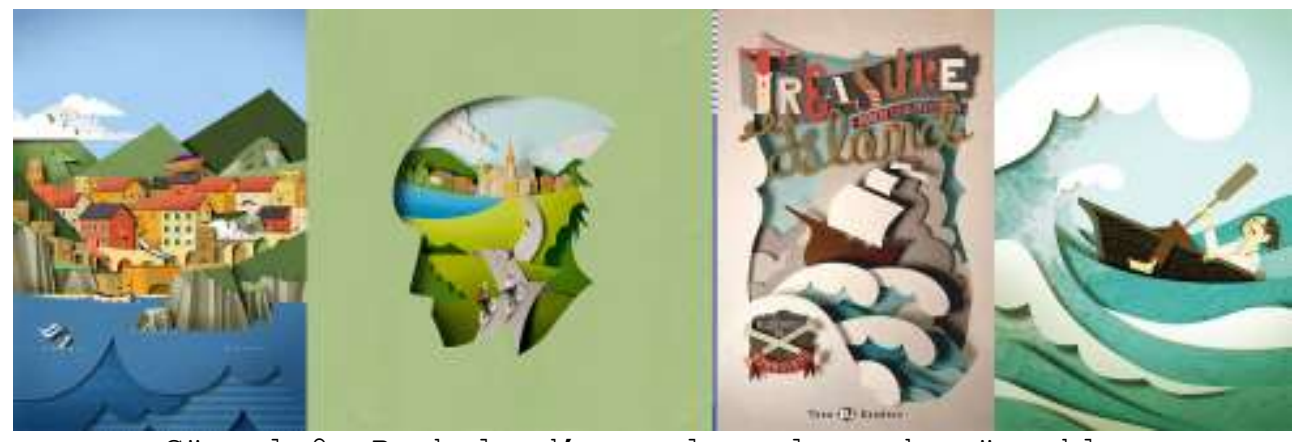

Görsel 9. Bomboland'ın çalışmalarından örnekler

(Figure 9. Examples of Bomboland's work)

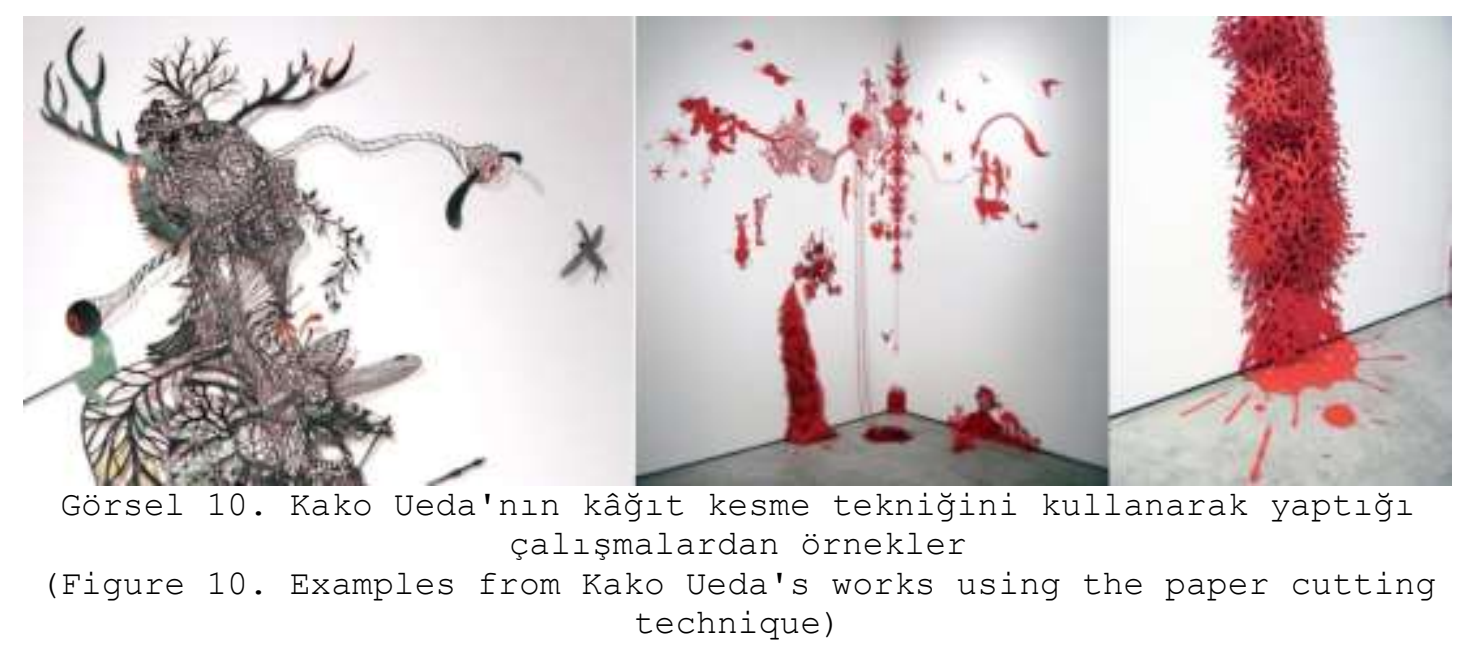




\section{SONUÇ VE ÖNERILER (CONCLUSION AND RECOMMENDATIONS)}

Kâğıt kesme tekniği Çin'de ortaya çıktığı günden bu yana büyük bir gelişim göstermiş ve insanlar tarafından benimsenen bir sanat formu haline gelmiştir. Kimi sadece sembolik amaçlarla ya da o kültürün bir gerekliliği haline geldiği için üretmiş kimi ise yaratıcı bir ifade dili olarak bu tekniği kendi sanatsal anlayışı doğrultusunda kullanmıştır. Bazıları ise sadece kendilerini iyi hissetmek amacıyla bu teknikle çalışmalar yapmıştır. Hangi amaçlarla yapıldığı değişkenlik gösterse de geleneksel kâğıt kesme tekniğinin ötesinde renk, boyut, kesim tekniği, dijital üretim gibi birçok konuda zenginleşerek çağdaş sanat ve tasarım alanında kendine yer edinmiştir. İlüistratörler, grafik tasarımcılar kağıdı kretuar yardımıyla keserek oluşturabildiği gibi tamamen dijital ortamda da kağıt kesme tekniği izlenimi verebilmektedir ya da her ikisini bir arada da kullanabilmektedir. Bu çalışmalar kimi zaman mekanla birlikte düşünülerek büyük boyutlarda da çalışılabilir. Kâğıt kesme tekniği ile oluşturdukları çalışmalarını sanatçılar, tasarımcılar, illüstratörler dünya çapında izleyiciyle buluşturabilmektedir.

\section{NOT (NOTICE)}

Bu çalışma 2020 yılında H. Ü. Güzel Sanatlar Enstitüsü tarafından kabul edilen "Kağıt kesme (Cut Out) Tekniğiyle Çocuklara Yönelik Etkileşimli Elektronik Kitap Tasarımı" isimli Yüksek Lisans tezinden hazırlanmıştır.

\section{ÇIKAR ÇATIŞMASI (CONFLICT OF INTEREST)}

Yazar çıkar çatışması bildirmemiştir.

\section{FINANSAL AÇIKLAMA (FINANCIAL DISCLOSURE)}

eder.

Yazar bu çalışma için herhangi bir mali destek almadığını beyan

\section{ETIK STANDARTLAR BEYANI (DECLARATION OF ETHICAL STANDARDS)}

Bu makalenin yazarı, bu çalışmada kullanılan materyal ve yöntemlerin etik kurul izni ve/veya yasal-özel izin gerektirmediğini beyan eder.

\section{KAYNAKLAR (REFERENCES)}

[1] Fey, C.Y., (2011). The cut: refiguring traditional chinese paper-cutting. Doctoral dissertation. Auckland University of Technology.

[2] Gildersleeve, O., (2014). Paper cut: an exploration into the contemporary world of papercraft art and illustration. Rockport Publishers.

[3] Guo, C., (2018). Creative research in papercut art and graphic design. In 6th International Conference on Social Science, Education and Humanities Research. Atlantis Press.

[4] Kaygusuz, B.G., (2017). Bir güncel sanat pratiği olarak katı', Of Paper-Cut (Katı') as a Modern Art. Z. Kurtaslan (Ed.). Kültür-Sanat-Edebiyat-Eğitim ve Mimarlık Üzerine Akademik Araştırmalar, 15-18 Ağustos 2017. 193-208. Konya: Eğitim Yayınevi.

[5] Ketenci, H.F. ve Bilgili, C., (2006). Görsel iletişim ve grafik tasarımı. İstanbul: Beta.

[6] Lianjing, M.A. and Yichuan, W.A.N.G., (2016). Artistic innovation of famous paper-cutting artist wang xiaying. Journal of Landscape Research, 8(6):142-144. 
[7] Miller, M. and Zhou, T., (2014). Scissors, paper, poetry: the interaction between chinese folk art and contemporary art practice. Journal of Illustration, 1(1):101-121.

[8] Özel Sağlamtimur, Z., (2010). Dijital sanat. Anadolu Üniversitesi Sosyal Bilimler Dergisi, $10(3)$ :213-238.

[9] Paper Cutting, (1964). Ankara: Milli Kütüphane.

[10] Ryan, R. and Avella, N., (2011). Paper cutting book: contemporary artists, Timeless Craft. Chronicle Books.

[11] Songür Dağ, E., (2015). Illüstrasyonun İkinci Altın Çağı. İstanbul: Grafik Kitaplığı.

[12] Görsel 1. Katı' sanatından örnekler. Erişim: 12.10.2020. https://www.kulturportali.gov.tr/portal/katisanati.

[13] Görsel 2. Lu Shengzhong'un kâğıt kesme çalışmaları. Erişim: 17.10.2020. http://www. chambersfineart.com/artists/lushengzhong .

[14] Görsel 2. Kyle Bean'in kâğıdı keserek oluşturduğu Louis Vuitton için yaptığı çalışmalarından örnekler. Erişim: 17.10.2020. https://kylebean.co.uk/.

[15] Görsel 4. Mia Pearlman'ın kâğıt kesme çalışması. Erişim: 17.10 .2020 . https://miapearlman.com/CUT_PAPER/TUMULT/TUMULT_center.jpg .

[16] Görsel 5. Elsa Mora'nın kâğıt kesme çalışmaları- Erişim: 17.10.2020. https://elsita.typepad.com/elsita/papercuts-by-elsamora.html.

[17] Görsel 6. Helen Musselwhite'ın renkli kâğıt kesme çalışmasından bir örnek. Erişim: 17.10.2020. https://helenmusselwhite.com/.

[18] Görsel 7. Eiko Ojala'nın kâğıt kesme tekniğiyle yaptığı çalışmalardan örnekler. Erişim: 17.10.2020. https://freeyork.org/art/eiko-ojalas-digital-papercutillustrations/.

[19] Görsel 9. Bomboland'ın çalışmalarından örnekler. Erişim:17.10.2020. https://www.designandpaper.com/bomboland/.

[20] Görsel 10. Kako Ueda'nın kâğıt kesme tekniğini kullanarak yaptığı çalışmalardan örnekler. Erişim:17.10.2020. https: / / www. kakoueda.com/cut-paper.

[21] https://freeyork.org/art/eiko-ojalas-digital-papercutillustrations/. Erişim:03.02.2010. 